(c) American Dairy Science Association, 2004.

\title{
Effect of Alfalfa Forage Preservation Method and Particle Length on Performance of Dairy Cows Fed Corn Silage-Based Diets and Tallow
}

\author{
S. G. Onetti, S. M. Reynal, and R. R. Grummer \\ Department of Dairy Science, \\ University of Wisconsin, Madison, 53706-1284
}

\begin{abstract}
A study was conducted to evaluate the effect of including alfalfa preserved either as silage or long-stem or chopped hay on DMI and milk fat production of dairy cows fed corn silage-based diets with supplemental tallow (T). Fifteen Holstein cows that averaged 117 DIM were used in a replicated $5 \times 5$ Latin square design with 21-d periods. Treatments (DM basis) were: 1) $50 \%$ corn silage: $50 \%$ concentrate without T (CS); 2) $50 \%$ corn silage: $50 \%$ concentrate with $2 \% \mathrm{~T}$ (CST); 3 ) $25 \%$ corn silage: $25 \%$ short-cut alfalfa hay:50\% concentrate with $2 \%$ T SAHT); 4) 25\% corn silage:25\% long-cut alfalfa hay:50\% concentrate with $2 \%$ T (LAHT); and 5) $25 \%$ corn silage: $25 \%$ alfalfa silage: $50 \%$ concentrate with $2 \%$ $\mathrm{T}$ (AST). Cows were allowed ad libitum consumption of a TMR fed 4 times daily. Diets averaged $16.4 \% \mathrm{CP}$ and $30.3 \%$ NDF. Including $2 \% \mathrm{~T}$ in diets with corn silage as the sole forage source decreased DMI and milk fat percentage and yield. Replacing part of corn silage with alfalfa in diets with $2 \% \mathrm{~T}$ increased milk fat percentage and yield. The milk fat of cows fed CST was higher in trans-10 C18:1 than that of cows fed diets with alfalfa. No effect of alfalfa preservation method or hay particle length was observed on DMI and milk production. The milk fat percentage and yield were lower, and the proportion of trans-10 C18:1 in milk fat was higher for cows fed LAHT than for cows fed SAHT. Alfalfa preservation method had no effect on milk fat yield. Ruminal $\mathrm{pH}$ was higher for cows fed alfalfa in the diets, and it was higher for cows fed LAHT than SAHT. Feeding alfalfa silage or chopped hay appears to be more beneficial than long hay in sustaining milk fat production when $2 \% \mathrm{~T}$ is fed with diets high in corn silage. These results support the role of trans fatty acids in milk fat depression.
\end{abstract}

(Key words: tallow, milk fat, alfalfa, particle length)

Abbreviation key: A:P = ruminal acetate to propionate ratio; $\mathbf{A S T}=25 \%$ corn silage: $25 \%$ alfalfa si-

Received April 18, 2003.

Accepted July 28, 2003.

Corresponding author: R. Grummer: e-mail: rgrummer@facstaff. wisc.edu lage: $50 \%$ concentrate with $2 \% \mathrm{~T} ; \mathbf{B H}=$ biohydrogenation; CLA = conjugated linoleic acid; $\mathbf{C S}=50 \%$ corn silage: $50 \%$ concentrate without $\mathrm{T} ; \mathbf{C S T}=50 \%$ corn silage: $50 \%$ concentrate with $2 \% \mathrm{~T} ; \mathbf{F A}=$ fatty acid; LAHT $=25 \%$ corn silage: $25 \%$ long-cut alfalfa hay: $50 \%$ concentrate with $2 \% \mathrm{~T}$; SAHT $=25 \%$ corn silage $: 25 \%$ short-cut alfalfa hay:50\% concentrate with $2 \% \mathrm{~T} ; \mathbf{T}=$ tallow.

\section{INTRODUCTION}

The differential responses to dietary fats observed when feeding different basal diets to dairy cows have been attributed to diet $\times$ fat interactions. Smith et al. (1993) showed that the depression in milk production and fat percentage observed when cottonseed and tallow (T) were added to corn silage diets was overcome by replacing 25 or $50 \%$ of the corn silage with alfalfa hay. Onetti et al. (2001) indicated that supplementing 2 and $4 \% \mathrm{~T}$ or choice white grease to diets containing processed high grain hybrid corn silage as the sole forage source had negative effects on rumen fermentation, DMI, and milk fat percentage. A study designed to evaluate whether replacing 25 or $50 \%$ of corn silage with alfalfa silage, typical forage fed in the Midwest, would reverse this negative impact (Onetti et al., 2002) showed no beneficial effect. We hypothesized that the reason for the differences in our findings compared with the study by Smith et al. (1993) was the use of alfalfa silage vs. alfalfa hay. Grant and Weidner (1992) observed that replacing approximately $15 \%$ of alfalfa silage with alfalfa hay, when $11.6 \%$ whole soybeans (DM basis) were fed, increased milk fat percentage and had no effect on $4 \%$ FCM. Total chewing time in that study was greatest for diets with alfalfa hay; this was mainly due to increased rumination. Cows consuming diets consisting of $55 \%$ alfalfa hay spent more time ruminating and chewing per kilogram of NDF than cows consuming the same amount of alfalfa silage (Nelson and Satter, 1990). Rumination and total chewing activities have been associated with increased saliva output, which plays an essential role in buffering acids produced during rumen fermentation and stabilizing rumen pH (Beauchemin and Buchanan-Smith, 1989; Al- 
len, 1997). Replacing alfalfa silage with coarsely chopped alfalfa hay increased rumination activity and numerically increased mean ruminal $\mathrm{pH}$ (Allen and Grant, 2000). Most of the studies that observed increased rumination and rumen $\mathrm{pH}$ when replacing alfalfa silage by alfalfa hay also observed increased particle size in the diets.

Milk fat depression is a consequence of shifts in biohydrogenation (BH) pathways, accumulation of trans fatty acids (FA) in the rumen, and subsequent inhibition of milk fat synthesis in the mammary gland (Bauman and Griinari, 2001). Kalscheur et al. (1997) observed reduced duodenal trans FA flow, decreased trans FA content in milk, and increased milk fat percentage when buffer was added to high-concentrate diets, implying a direct effect of $\mathrm{pH}$ on ruminal $\mathrm{BH}$. Therefore, we hypothesized that alfalfa hay, particularly longstem alfalfa hay, but not alfalfa silage would alleviate T-induced milk fat depression of dairy cows fed corn silage-based diets by decreasing trans FA formation in the rumen.

The objective of this study was to evaluate the effects of including alfalfa preserved either as silage or chopped or long-stem hay on chewing behavior, ruminal $\mathrm{pH}$, trans $\mathrm{FA}$ formation in the rumen, and milk fat production of dairy cows fed corn silage-based diets with supplemental T. A second objective was to investigate whether the milk fat depression observed when $\mathrm{T}$ is fed with diets with corn silage as the only forage source is related to incomplete $\mathrm{BH}$ of polyunsaturated FA.

\section{MATERIALS AND METHODS}

\section{Animals}

Fifteen multiparous Holstein cows that averaged $( \pm$ SD) $117 \pm 28 \mathrm{DIM}$ and $688 \pm 7 \mathrm{~kg}$ of BW were used in a replicated $5 \times 5$ Latin square design with 21 -d periods. Two squares consisted of cows with rumen fistulas and one of cows without rumen fistulas. Cows within a square were assigned randomly to dietary treatments. Treatment sequences were ordered to minimize residual or carryover effects of any treatment in the succeeding period. Cows were housed individually in a tiestall and stanchion barn and had free-choice access to water. All cows were injected with $250 \mathrm{mg}$ of bST (Posilac, Monsanto Company, St. Louis, MO) on the same day every week. Animals were handled according to the recommendations and procedures approved by the Animal Care and Use Committee of the College of Agriculture and Life Science of the University of WisconsinMadison. Two cows were removed from the study due to teat injuries. One cow was removed during the first experimental period, and a replacement cow was used for the rest of the experiment. The second cow was removed from the experiment during the last period; therefore, information of the preceding 4 periods was used for this particular cow.

\section{Diets}

Experimental treatments, as a percentage of total diet DM, were: 1) $50 \%$ corn silage: $50 \%$ concentrate without $\mathrm{T}(\mathbf{C S}) ; 2) 50 \%$ corn silage: $50 \%$ concentrate with $2 \%$ T (CST); 3) 25\% corn silage: $25 \%$ short alfalfa hay:50\% concentrate with $2 \% \mathrm{~T}$ (SAHT); 4) 25\% corn silage:25\% long alfalfa hay:50\% concentrate with $2 \% \mathrm{~T}$ (LAHT); and 5) $25 \%$ corn silage: $25 \%$ alfalfa silage:50\% concentrate with $2 \% \mathrm{~T}$ (AST). Diets were formulated to be isonitrogenous and to meet or exceed the National Research Council (NRC, 2001) nutrient allowances for a lactating cow (623 kg of BW and 150 DIM) producing $36.2 \mathrm{~kg} / \mathrm{d}$ of milk with $3.3 \%$ fat and eating $24.7 \mathrm{~kg}$ of DM. Ingredient composition of experimental diets is shown in Table 1 . When replacing corn silage with alfalfa in diets containing $\mathrm{T}$, the amount of corn grain was increased and soybean meal was reduced to make diets isonitrogenous and isoenergetic. The corn hybrid used was Cargill 3677 (Cargill Inc., Minneapolis, MN) and was selected for high grain yield to minimize treatment differences in NDF. Corn silage was processed (2$\mathrm{mm}$ roll clearance) and chopped at a theoretical length of $12 \mathrm{~mm}$. Second crop alfalfa (Voyager II, Lemke Seeds, Mequon, WI) was harvested as hay in bales or as silage in an upright silo, on the same day. Theoretical length of chop of alfalfa silage was $10 \mathrm{~mm}$. Short hay was obtained by processing the long hay through a chopper (AgriMetal Inc., Wickham, QC, Canada). Average ( \pm SD) DM, NDF, and CP concentration of corn silage was $36.0 \pm 3.3,38.1 \pm 5.4$, and $8.5 \pm 0.3$; of alfalfa silage was $52.4 \pm 0.9,42.3 \pm 1.7$, and $18.7 \pm 0.7$; of long hay was $89.0 \pm 1.8,47.1 \pm 0.4$, and $18.1 \pm 0.7$; and of short hay was $89.0 \pm 1.8,45.9 \pm 1.8$, and $15.8 \pm 0.2 \%$, respectively. Tallow was incorporated into concentrates and then added to TMR. Fatty acid composition (g/100 g of FA) of T (Packerland Packing Co., Inc, Green Bay, WI) was 2.6\% C14:0, 24.2\% C16:0, 3.4\% C16:1, 19.2\% C18:0, $44.2 \% \mathrm{C} 18: 1,3.4 \% \mathrm{C} 18: 2,0.3 \% \mathrm{C} 18: 3$, and $2.7 \%$ other FA. Cows were fed the diets 4 times daily $(0900,1500$, 2100 , and $0300 \mathrm{~h}$ ) as a TMR to allow $10 \%$ feed refusal on an as-fed basis. For LAHT, long-stem hay was handmixed in the manger with the rest of the feed ingredients that were fed as a TMR.

Nutrient composition of experimental diets is shown in Table 2. Supplemental $\mathrm{T}$ increased $\mathrm{NE}_{\mathrm{L}}$ content of diets by $0.07 \mathrm{Mcal} / \mathrm{kg}$ DM. Neutral detergent fiber concentration was 1.6 percentage units lower for CST compared with CS, likely due to less inclusion of soybean hulls in this diet. Content of NFC was similar for CS 
Table 1. Ingredient composition (\% of DM) of experimental diets. ${ }^{1}$

\begin{tabular}{|c|c|c|c|c|c|}
\hline & CS & CST & SAHT & LAHT & $\mathrm{AST}$ \\
\hline Corn silage & 50.0 & 50.0 & 25.0 & 25.0 & 25.0 \\
\hline Alfalfa hay & & & 25.0 & 25.0 & \\
\hline Alfalfa silage & & & & & 25.0 \\
\hline Corn grain & 18.0 & 18.0 & 22.8 & 23.0 & 23.0 \\
\hline Soybean hulls & 14.4 & 11.2 & 9.6 & 9.6 & 9.6 \\
\hline Soybean meal, $48 \%$ & 6.4 & 7.4 & 5.0 & 5.0 & 5.0 \\
\hline Distiller's grains, dry & 5.0 & 5.25 & 5.25 & 5.25 & 5.25 \\
\hline Meat and bone meal & 3.0 & 3.0 & 3.0 & 3.0 & 3.0 \\
\hline Blood meal & 1.0 & 1.0 & 1.0 & 1.0 & 1.0 \\
\hline Urea & 0.4 & 0.4 & 0.2 & & \\
\hline Limestone & 0.9 & 0.9 & 0.4 & 0.4 & 0.4 \\
\hline Magnesium oxide & 0.05 & 0.05 & & & \\
\hline Trace mineral salt ${ }^{2}$ & 0.5 & 0.5 & 0.45 & 0.45 & 0.45 \\
\hline Vitamin $\operatorname{mix}^{3}$ & 0.3 & 0.3 & 0.3 & 0.3 & 0.3 \\
\hline Tallow & & 2.0 & 2.0 & 2.0 & 2.0 \\
\hline
\end{tabular}

${ }^{1} \mathrm{CS}=50 \%$ corn silage $+50 \%$ concentrate with $0 \%$ tallow; CST $=50 \%$ corn silage $+50 \%$ concentrate with $2 \%$ tallow; SAHT $=25 \%$ corn silage $+25 \%$ short alfalfa hay $+50 \%$ concentrate with $2 \%$ tallow; LAHT $=$ $25 \%$ corn silage $+25 \%$ long alfalfa hay $+50 \%$ concentrate with $2 \%$ tallow; AST $=25 \%$ corn silage $+25 \%$ alfalfa silage $+50 \%$ concentrate with $2 \%$ tallow.

${ }^{2}$ Contained $0.55 \% \mathrm{Mn}, 0.55 \% \mathrm{Zn}, 0.35 \% \mathrm{Fe}, 0.14 \% \mathrm{Cu}, 0.008 \% \mathrm{I}, 0.006 \% \mathrm{Se}$, and $0.002 \% \mathrm{Co}$.

${ }^{3}$ Contained $3304 \mathrm{IU} / \mathrm{g}$ of vitamin A, $1101 \mathrm{IU} / \mathrm{g}$ of vitamin D, and $11 \mathrm{IU} / \mathrm{g}$ of vitamin $\mathrm{E}$.

and CST, and it was slightly lower for alfalfa diets with T compared with CST. Fatty acid concentration of diets with $2 \% \mathrm{~T}$ was similar for the different alfalfa treatments and was slightly higher for CST, likely due to higher contribution of FA from corn silage. Mean particle size and particle size distribution of experimental diets are presented in Table 3. Mean particle size and distribution were similar for both diets, with corn silage as the only forage source. Mean particle sizes of SAHT and AST were similar and averaged $3.5 \mathrm{~mm}$. Particle size distribution of these 2 treatments was also similar, with SAHT having slightly higher proportion of particles in the pan, probably due to the breakdown of particles during chopping. Including $25 \%$ long-stem alfalfa hay in diets increased mean particle size of the diet and the proportion of longer particles.

\section{Sampling and Laboratory Analysis}

Dry matter content of forages and concentrates was determined weekly using a $60^{\circ} \mathrm{C}$ forced-air oven; results were used to adjust as-fed ratios in the TMR. The TMR

Table 2. Chemical composition of experimental diets. ${ }^{1}$

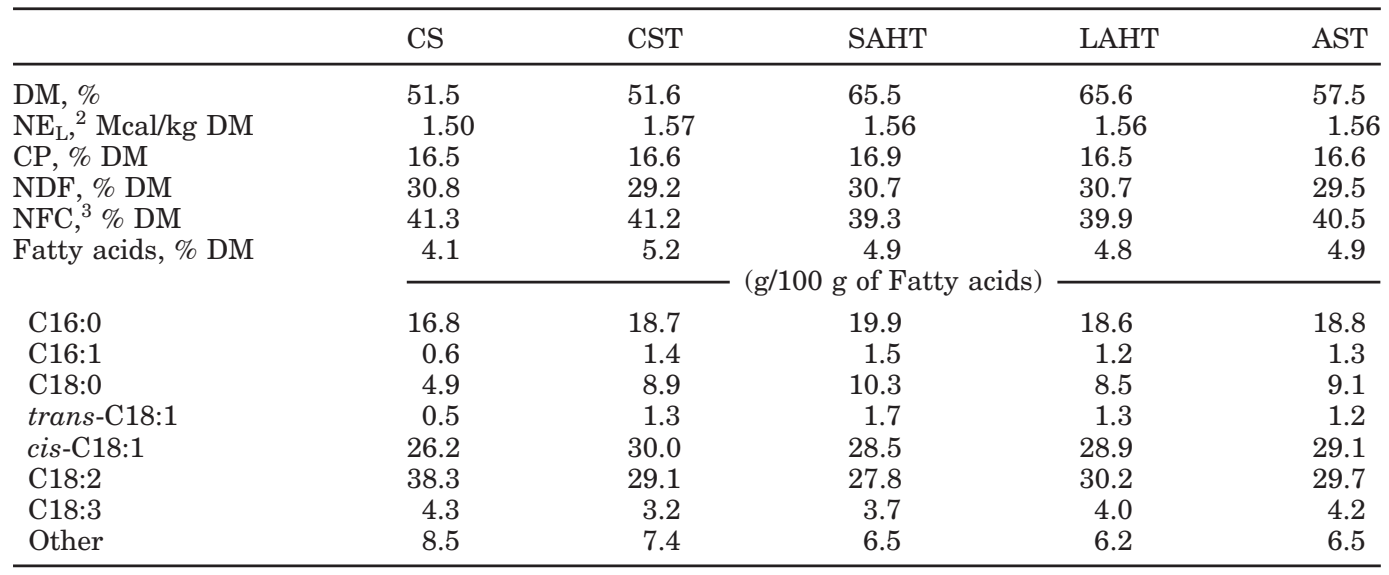

${ }^{1} \mathrm{CS}=50 \%$ corn silage $+50 \%$ concentrate with $0 \%$ tallow; CST $=50 \%$ corn silage $+50 \%$ concentrate with $2 \%$ tallow; $\mathrm{SAHT}=25 \%$ corn silage $+25 \%$ short alfalfa hay $+50 \%$ concentrate with $2 \%$ tallow; LAHT $=$ $25 \%$ corn silage $+25 \%$ long alfalfa hay $+50 \%$ concentrate with $2 \%$ tallow; AST $=25 \%$ corn silage $+25 \%$ alfalfa silage $+50 \%$ concentrate with $2 \%$ tallow.

${ }^{2}$ Calculated (NRC, 2001).

${ }^{3}$ Nonfibrous carbohydrates. 
Table 3. Particle size distribution ( \pm SD) expressed as percentage of wet sample on screen and mean particle size $\left( \pm\right.$ SD) of experimental diets ${ }^{1}$ offered to cows.

\begin{tabular}{lrrrrr}
\hline & \multicolumn{1}{c}{ CS } & \multicolumn{1}{c}{ CST } & \multicolumn{1}{c}{ SAHT } & \multicolumn{1}{c}{ LAHT } & \multicolumn{1}{c}{ AST } \\
\hline Screen size ${ }^{2} \mathrm{~mm}$ & & & & & \\
26.9 & $0.3 \pm 0.1$ & $0.3 \pm 0.1$ & $1.4 \pm 0.5$ & $12.0 \pm 0.9$ & $0.8 \pm 0.1$ \\
18.0 & $1.4 \pm 0.3$ & $1.2 \pm 0.3$ & $4.9 \pm 1.0$ & $3.0 \pm 0.5$ & $4.7 \pm 0.4$ \\
8.98 & $27.2 \pm 1.1$ & $27.7 \pm 1.1$ & $19.9 \pm 1.5$ & $15.9 \pm 0.6$ & $22.0 \pm 0.8$ \\
5.61 & $12.0 \pm 0.7$ & $12.1 \pm 0.4$ & $10.8 \pm 0.6$ & $9.9 \pm 0.3$ & $13.2 \pm 0.5$ \\
1.65 & $31.3 \pm 1.7$ & $31.1 \pm 0.7$ & $30.4 \pm 1.4$ & $28.4 \pm 0.4$ & $30.9 \pm 1.2$ \\
Pan & $27.8 \pm 2.3$ & $27.7 \pm 1.5$ & $32.5 \pm 2.5$ & $30.8 \pm 0.7$ & $28.4 \pm 1.4$ \\
MPS, ${ }^{3} \mathrm{~mm}$ & $3.6 \pm 0.2$ & $3.6 \pm 0.1$ & $3.4 \pm 0.3$ & $4.1 \pm 0.1$ & $3.6 \pm 0.1$ \\
\hline
\end{tabular}

${ }^{1} \mathrm{CS}=50 \%$ corn silage $+50 \%$ concentrate with $0 \%$ tallow; CST $=50 \%$ corn silage $+50 \%$ concentrate with $2 \%$ tallow; $\mathrm{SAHT}=25 \%$ corn silage $+25 \%$ short alfalfa hay $+50 \%$ concentrate with $2 \%$ tallow; LAHT $=$ $25 \%$ corn silage $+25 \%$ long alfalfa hay $+50 \%$ concentrate with $2 \%$ tallow; AST $=25 \%$ corn silage $+25 \%$ alfalfa silage $+50 \%$ concentrate with $2 \%$ tallow.

${ }^{2}$ Square hole diagonal.

${ }^{3} \mathrm{MPS}=$ geometric mean particle size.

amount offered and refused was measured daily. Orts were collected on d 17 to 19 of each period and dried $48 \mathrm{~h}$ in a $60^{\circ} \mathrm{C}$ forced-air oven for DMI determination. Forage and concentrate samples were collected weekly, dried $48 \mathrm{~h}$ in a $60^{\circ} \mathrm{C}$ forced-air oven, and ground to pass a 2-mm Wiley mill screen (Arthur H. Thomas, Philadelphia, PA). Organic matter was determined by oven drying at $550^{\circ} \mathrm{C}$ for $720 \mathrm{~min}$. Samples were analyzed for NDF (Mertens, 1999), CP (AOAC, 1990), and FA (Sukhija and Palmquist, 1988). The nonfibrous carbohydrate component was calculated as 100 - (NDF + ether extract $+\mathrm{CP}+$ ash). Ether extract content was estimated from FA analysis as FA + 1 (NRC, 2001). Diets and orts particle size and distribution were determined using an oscillating screen particle separator according to the American Society of Agricultural Engineers standard S424 (American National Standards Institute, 1988). The separator has 5 screens with nominal diagonal openings of $26.90,18.00,8.98,5.61$, and $1.65 \mathrm{~mm}$ and a pan.

Cows were milked twice daily, and milk production was recorded at each milking during the final $5 \mathrm{~d}$ of each period. Milk samples from the a.m. and p.m. milking were collected on 5 consecutive days ( $d 7$ to 21 of each period). They were analyzed for fat, CP, and solidsnot-fat by infrared analysis (AgSource Milk Analysis Laboratory, Menomonie, WI). Milk samples from d 17 and 18 were composited for FA analysis. Milk fat was isolated as described by Stine et al. (1954). Fatty acid transesterification was performed according to the method described by Chouinard et al. (1999). Fatty acids methyl esters were injected into a gas chromatograph (Perkin Elmer Autosystem, Norwalk, CT) equipped with a $100-\mathrm{m}$ (i.d., $0.25 \mathrm{~mm}$ ) WCOT-fused silica capillary column coated with CP-Sil 88 (Chrompack \#CP7489, Varian Inc., Walnut Creek, CA). Helium was utilized as the carrier gas. Three different runs were performed for each sample. The FA profile was determined using a temperature gradient run (50 to $190^{\circ} \mathrm{C}$ at $\left.4^{\circ} \mathrm{C} / \mathrm{min}\right)$. An isothermal run $\left(160^{\circ} \mathrm{C}\right)$ was used to separate most trans-octadecenoic FA. A second isothermal run $\left(180^{\circ} \mathrm{C}\right)$ was used to separate trans -15 , and trans-13/14 from cis-9 C18:1 that coelute as one peak during the isothermal run at $160^{\circ} \mathrm{C}$. Peaks were identified utilizing individual FA from Supelco Inc. (Bellefonte, PA), Sigma Chemical Co. (St. Louis, Mo), and Matreya Inc. (Pleasant Gap, PA). To convert area percentages to weight percentages, response correction factors for each FA methyl ester were calculated utilizing a certified butter oil (CRM 164, Commission of the European Communities, Community Bureau of Reference, Brussels, Belgium).

Rumen fluid was sampled from fistulated cows before $(0 \mathrm{~h})$ and at 2, 4, 6, 8, and $10 \mathrm{~h}$ after the $0900 \mathrm{~h}$ feeding on $\mathrm{d} 21$ of the experimental period. Samples were taken from 5 different locations in the rumen with a metal filter probe. Rumen $\mathrm{pH}$ was determined immediately after the samples were collected (Twin $\mathrm{pH}$-meter model B-213, Spectrum Technologies Inc., Plainfield, IL). One milliliter of rumen fluid was acidified with $20 \mu \mathrm{L}$ of $50 \% \mathrm{H}_{2} \mathrm{SO}_{4}$ and frozen until analysis for VFA by GLC (Perkin Elmer Autosystem, Norwalk, CT) as described by Bal et al. (2000), and $1 \mathrm{~mL}$ was mixed with $20 \mu \mathrm{L}$ of $50 \%$ TCA and frozen until analysis for $\mathrm{NH}_{3}-\mathrm{N}$ (Chaney, 1962).

Digesta flow at the omasal canal in rumen-cannulated cows $(n=5)$ was determined by continuous marker infusion (France and Siddons, 1986). Indigestible NDF (Huhtanen et al., 1994), $\mathrm{YbCl}_{3}$ (Siddons et al., 1985), and Co-EDTA (Uden et al., 1980) were used as markers for large particle phase, small particle phase, and fluid phase, respectively. Ytterbium chloride and Co-EDTA were continuously infused into the rumen at a constant rate of $2.9 \mathrm{~g}$ of $\mathrm{Co} / \mathrm{d}$ and $4.2 \mathrm{~g}$ of $\mathrm{Yb} / \mathrm{d}$ from d 15 to 20 . 
Digesta flowing out of the rumen was collected using an alternating vacuum and pressure system developed by Huhtanen et al. (1997) and modified by Ahvenjärvi et al. (2000). Spot samples (200 ml) were collected from the omasal canal every $4 \mathrm{~h}$ during d 18 to 20 of the experimental periods. Time of sampling was advanced each day such that the composited samples represented sampling from every hour over a period of $12 \mathrm{~h}(0900$ to $2000 \mathrm{~h})$. Omasal composites $(2.4 \mathrm{~L})$ were separated into 3 digesta phases as follows. Samples were squeezed through one layer of cheesecloth, and solids retained were defined as the large particle phase. The filtrate was centrifuged at $10,000 \times g$ at $4^{\circ} \mathrm{C}$ for $15 \mathrm{~min}$. The supernatant was defined as the fluid phase, and the pellet as the small particle phase. Digesta phases were frozen, freeze-dried, and ground to pass a 1-mm Wiley mill screen (Arthur H. Thomas, Philadelphia, PA) and analyzed for NDF (Mertens, 1999) and FA (Sukhija and Palmquist, 1988). Concentrations of $\mathrm{Co}$ and $\mathrm{Yb}$ in omasal phases were determined by direct current plasma emission spectroscopy (Spectra Metrics, Inc., subsidiary of Beckman Instruments, Inc., Andover, MA; Combs and Satter, 1992).

Chewing behavior was monitored visually on $\mathrm{d} 16$ of each experimental period during $24 \mathrm{~h}$. Eating and rumination activities were noted every $5 \mathrm{~min}$ and were assumed to persist for the entire 5-min interval. Chewing activities per unit of DM and NDF intake were calculated for each cow using mean intakes for each period.

\section{Calculations}

Concentrations of $\mathrm{Co}, \mathrm{Yb}$, and indigestible NDF in large and small particles phases, and of $\mathrm{Co}$ and $\mathrm{Yb}$ in fluid phase of omasal digesta composites, were used to reconstitute omasal true digesta flowing out of the rumen based on the triple-marker method (France and Siddons, 1986). Fatty acid flow was calculated by multiplying DM flow by the concentration of FA in the reconstituted omasal true digesta.

Apparent ruminal BH of individual C18 unsaturated FA was calculated as described by Wu et al. (1991):

$$
\mathrm{BH}, \%=100-[100 \times(\text { FUFA/FTFA }) /(\text { IUFA/ITFA })]
$$

where FUFA = omasal true digesta flow of individual unsaturated $\mathrm{C} 18$ fatty acid, FTFA = omasal true digesta flow of total C18 FA, IUFA = intake of individual unsaturated C18 fatty acid, and ITFA = intake of total C18 FA.

\section{Statistical Analysis}

All data were analyzed using the mixed procedure of SAS (SAS User's Guide, 2001). Dry matter and NDF intakes, milk production and composition, and chewing behavior were analyzed as a replicated $5 \times 5$ Latin square. The model included the fixed effects of square, period, treatment, and the interactions square $\times$ period, square $\times$ treatment, and period $\times$ treatment. Cow within square was the specified term for the random statement. Ruminal $\mathrm{pH}, \mathrm{NH}_{3}-\mathrm{N}$, and VFA from fistulated cows were analyzed by time as repeated measures in a replicated $5 \times 5$ Latin square design. The final model included the effects of square, period, treatment, time, and the interaction of treatment $\times$ time. The specified term for the random statement was cow within square and period $\times$ treatment $\times$ cow within square. The covariance structure used to fit the model was selected based on the Akaike's information criterion of the mixed models of SAS (SAS User's Guide, 2001). Intake and flow of FA were analyzed in a single Latin square, and the model used included the fixed effects of period and treatment and the random effect of cow.

Preplanned statistical contrasts were used to test the effect of $\mathrm{T}$ supplementation when corn silage was the only forage source (CS vs. CST); the effect of replacing $50 \%$ of corn silage with alfalfa in diets containing $\mathrm{T}$ (CST vs. SAHT + LAHT + AST); and the effect of hay particle length (SAHT vs. LAHT) and of alfalfa preservation method (SAHT vs. AST) in diets with $2 \%$ supplemental T. Least square means are reported. Unless otherwise stated, significance was declared at $P<0.05$. Trends towards significance were considered at $0.05 \leq$ $P<0.15$.

\section{RESULTS AND DISCUSSION}

\section{Intakes of Nutrients and Milk Yield and Composition}

Table 4 shows intakes of nutrients and milk yield and composition as affected by experimental diets. Dry matter intake of cows fed CST was $1.6 \mathrm{~kg} / \mathrm{d}$ lower $(P<$ 0.01 ) than that of cows fed CS. A similar response to supplementing $2 \% \mathrm{~T}$ with diets high in corn silage was observed in a previous study (Onetti et al., 2001). Replacing $50 \%$ of the corn silage with alfalfa tended $(P$ $<0.12$ ) to increase DMI of cows when $2 \% \mathrm{~T}$ was fed. Similarly, Onetti et al. (2002) and Ruppert et al. (2003) reported increased DMI as the alfalfa silage:corn silage ratio of diets containing $T$ increased. Smith et al. (1993) observed similar DMI of cows fed $2.5 \% \mathrm{~T}$ when 25 or $50 \%$ of the corn silage was replaced with alfalfa hay in the diets. There was a trend $(P<0.07)$ for a period $\times$ treatment interaction for DMI. The reasons for this trend are unknown, as no consistent pattern was observed in the interaction. However, no period $\times$ treatment interaction was detected for energy and fiber intakes. Intake of calculated $\mathrm{NE}_{\mathrm{L}}$ did not differ between diets and averaged $41.3 \mathrm{Mcal} / \mathrm{d}$ (data not shown). Intake 
Table 4. Effects of dietary treatments on nutrient intakes, milk production, and milk composition.

\begin{tabular}{|c|c|c|c|c|c|c|c|c|c|c|}
\hline & \multicolumn{5}{|c|}{ Treatment $^{1}$} & \multirow[b]{2}{*}{$\mathrm{SE}$} & \multicolumn{4}{|c|}{ Statistical contrasts $(P<)^{2}$} \\
\hline & $\mathrm{CS}$ & CST & SAHT & LAHT & AST & & A & B & $\mathrm{C}$ & $\mathrm{D}$ \\
\hline DMI, kg/d & 27.6 & 25.9 & 26.7 & 26.6 & 26.5 & 0.6 & 0.01 & 0.12 & NS & NS \\
\hline $\mathrm{NDFI},{ }^{3} \mathrm{~kg} / \mathrm{d}$ & 8.3 & 7.7 & 8.1 & 7.7 & 7.7 & 0.2 & 0.01 & NS & 0.11 & 0.10 \\
\hline Milk, kg/d & 44.9 & 44.3 & 44.8 & 44.3 & 43.6 & 1.8 & NS & NS & NS & NS \\
\hline Fat, $\%$ & 3.12 & 2.68 & 3.17 & 2.96 & 3.32 & 0.12 & 0.001 & 0.001 & 0.03 & 0.10 \\
\hline Fat, kg/d & 1.38 & 1.17 & 1.39 & 1.31 & 1.45 & 0.06 & 0.002 & 0.001 & 0.10 & NS \\
\hline Protein, \% & 3.03 & 2.96 & 2.93 & 2.94 & 2.84 & 0.04 & 0.02 & 0.01 & NS & 0.001 \\
\hline Protein, kg/d & 1.36 & 1.31 & 1.30 & 1.30 & 1.23 & 0.05 & NS & NS & NS & 0.05 \\
\hline $\mathrm{SNF}, \mathrm{kg} / \mathrm{d}$ & 3.9 & 3.8 & 3.8 & 3.8 & 8.7 & 0.16 & NS & NS & NS & NS \\
\hline
\end{tabular}

${ }^{1} \mathrm{CS}=50 \%$ corn silage $+50 \%$ concentrate with $0 \%$ tallow; $\mathrm{CST}=50 \%$ corn silage $+50 \%$ concentrate with $2 \%$ tallow; $\mathrm{SAHT}=25 \%$ corn silage $+25 \%$ short alfalfa hay $+50 \%$ concentrate with $2 \%$ tallow; LAHT $=$ $25 \%$ corn silage $+25 \%$ long alfalfa hay $+50 \%$ concentrate with $2 \%$ tallow; AST $=25 \%$ corn silage $+25 \%$ alfalfa silage $+50 \%$ concentrate with $2 \%$ tallow.

${ }^{2} \mathrm{~A}=\mathrm{CS}$ vs. CST; $\mathrm{B}=\mathrm{CST}$ vs. SAHT + LAHT + AST; C = SAHT vs. LAHT; D = SAHT vs. AST; NS = not significant.

${ }^{3}$ Neutral detergent fiber intake.

of NDF was lower $(P<0.01)$ for cows fed CST than for cows fed CS, probably due to a combination of lower DMI and a slightly lower NDF concentration in the diet. Replacing part of the corn silage with alfalfa had no effect on NDF intake. Neutral detergent fiber intake tended $(P<0.11)$ to be higher for cows fed SAHT than LAHT. This was likely due to selective sorting against long particles in the manger. Sorting was calculated according to Leonardi et al. (2003) as actual intake of particles retained on the top screen $(>26.9 \mathrm{~mm})$ expressed as a percentage of their predicted intake. Intake of particles retained on the top screen was $72 \%$ of predicted intake for cows fed LAHT. Because long particles usually are higher in NDF concentration than the TMR, sorting against them would likely result in lower NDF intake. The trend $(P<0.10)$ for higher NDF intake for cows fed SAHT compared with AST might be partly explained by the slightly lower NDF content of AST (30.7 and 29.5 for LAHT and AST, respectively, Table 2).

Milk production was not affected by dietary treatments and averaged $44.4 \mathrm{~kg} / \mathrm{d}$ (Table 4 ). Supplementing $2 \% \mathrm{~T}$ to diets with corn silage as the only forage source had different effects on milk yield response in previous studies, with decreased (Onetti et al., 2001), increased (Onetti et al., 2002), or no change (Onetti et al., 2003) in milk production. Different responses were likely due to differences in the effects of $\mathrm{T}$ on energy intake. No significant effect of forage combinations on milk yield was observed in the present study. Similarly, milk yield was not affected when different combinations of alfalfa silage or hay and corn silage were fed (Smith et al., 1993; Onetti et al., 2002; Ruppert et al., 2003).

Milk fat percentage and yield significantly $(P<0.002)$ decreased when $2 \% \mathrm{~T}$ was added to diets with corn silage as the sole forage source. These results agree with our previous results (Onetti et al., 2001, 2002) and with data from Ruppert et al. (2003). Replacing 50\% of the corn silage with alfalfa in the diets resulted in increased $(P<0.001)$ milk fat percentage and yield. In a previous experiment (Onetti et al., 2002), replacing 25 or $50 \%$ of the corn silage with alfalfa silage did not alleviate the negative effect of $2 \%$ supplemental $\mathrm{T}$ on milk fat production; however, milk fat yield increased linearly as the proportion of alfalfa silage in the diets increased independently of the fat content of the diet. Ruppert et al. (2003) showed that $\mathrm{T}$ tended to decrease milk fat content to a greater extent when the corn silage to alfalfa silage ratio in the basal diet was 40:10 than when it was 10:40 (DM basis). Similarly, Smith et al. (1993) reported that the depression in milk fat percentage observed when $2.5 \% \mathrm{~T}$ was fed with corn silage diets was overcome by replacing 25 or $50 \%$ of the corn silage with alfalfa hay. It is not possible to discern in the present study if the effects of including alfalfa on milk fat production are strictly due to a forage effect or if a $\mathrm{T} \times$ forage interaction occurred. Contrary to our expectations, cows fed LAHT had lower $(P<0.03)$ milk fat content and tended $(P<0.10)$ to produce less milk fat than cows fed SAHT. This effect appears to be related to selective sorting against long particles. Mean particle size of the consumed LAHT diet (calculated from actual intakes of material on individual screens and pan) was $3.7 \mathrm{~mm}$ and was lower than that of LAHT offered (Table 3 ); however, it was slightly higher than mean particle size of consumed SAHT, which remained identical to that of SAHT offered. When cow 4611 was excluded from the analysis because she consumed only $21 \%$ of long particles (mean particle size of consumed diet was $3.1 \mathrm{~mm}$ ), the trend towards a significant difference between LAHT and SAHT for milk fat yield disappeared. These results suggest that feeding long-stem hay might 
be less effective than chopped hay in sustaining milk fat production if sorting occurs in the manger. The extent of sorting by individual animals fed TMR has been shown to be extremely variable (Leonardi and Armentano, 2003). There was a trend $(P<0.10)$ for increased milk fat percentage when cows were fed AST compared with SAHT, and it was likely due to the slightly lower milk production, as milk fat yield was not affected.

Milk protein percentage was lower $(P<0.02)$ for cows fed CST than for cows fed CS; however, no effect of T was observed for milk protein yield. Decreased milk protein percentage without changes in milk protein yield due to supplemental fats has been reported elsewhere (Wu and Huber, 1994). Replacing 50\% of corn silage with alfalfa in diets containing $\mathrm{T}$ increased $(P<$ 0.01 ) milk protein percentage; this was primarily due to AST treatment. No effect of replacing corn silage with alfalfa was observed for protein yield. Feeding alfalfa hay of different particle length in diets containing $2 \% \mathrm{~T}$ did not affect milk protein percentage or yield of cows. When $2 \% \mathrm{~T}$ was fed, alfalfa silage significantly decreased milk protein percentage $(P<$ $0.001)$ and yield $(P<0.05)$ relative to alfalfa hay of similar particle length. Vagnoni and Broderick (1997) reported a greater increase in milk protein yield when RUP as fish meal was supplemented to cows fed alfalfa silage diets vs. alfalfa hay diets. These researchers concluded that protein status of cows fed alfalfa silage was poorer than that of cows fed alfalfa hay. No effect of dietary treatments was observed for solids-not-fat yield.

\section{Fatty Acid Composition of Milk Fat}

Fatty acid composition of milk fat is presented in Table 5. Fatty acid profile of milk fat was altered substantially when $2 \% \mathrm{~T}$ was included in diets, with corn silage as the only forage source. Proportion of shortchain FA (C4 to C14) in milk fat was decreased $(P<$ 0.001 ), and proportions of $\mathrm{C} 16: 0$ and $\mathrm{C} 18: 0$ were similar for cows fed CS and CST. Cows fed CST had significant higher proportion of total C18:1 and of cis-9, trans11 and trans-10, cis-12 conjugated linoleic acid (CLA) isomers. Content of trans-6/8, trans-9, and trans -10 C18:1, total trans-C18:1, and total trans-C18 FA (C18:1 isomers plus cis-9, trans-11 and trans-10, cis-12 CLA) were increased in milk fat of cows fed CST vs. cows fed $\mathrm{CS}$. These changes are consistent with changes in the FA profile observed during dietary induced milk fat depression and with previous experiments (Onetti et al., 2001, 2002) that reported milk fat depression when $2 \%$ supplemental $\mathrm{T}$ was fed with corn silage as the only forage source. Increased proportions of trans-10 C18:1 and trans-10, cis-12 CLA in milk fat support their role as inhibitors of milk fat synthesis (Griinari et al., 1998; Baumgard et al., 2000).

Replacing $50 \%$ of the corn silage with alfalfa in diets containing supplemental $\mathrm{T}$ did not affect the content of C4 to $\mathrm{C} 14 \mathrm{FA}$, tended $(P<0.14)$ to decrease content of C16:0, and significantly $(P<0.02)$ increased the proportion of C18:0, C18:2, and C18:3 in milk fat (Table 5). Proportion of the cis-9, trans-11 CLA isomer was not affected, and trans-10, cis-12 CLA isomer content was decreased $(P<0.04)$ when alfalfa replaced half of the corn silage in the diets. Milk fat of cows fed alfalfa in the diets had significant lower content of trans-6/8, trans-9, and trans-10 C18:1, and total trans-C18:1, and it had higher content of trans-12 C18:1. Decreased contents of trans-10 C18:1 and trans-10, cis-12 CLA in milk fat are in agreement with higher milk fat content and yield of cows fed 50\% of forage from alfalfa compared with cows fed corn silage as the only forage source (Table 4). Total trans-C18 FA content in milk fat was lower $(P<0.003)$ when alfalfa replaced corn silage.

Feeding LAHT relative to SAHT significantly $(P<$ $0.05)$ decreased C18:0, increased $(P<0.02) \mathrm{C} 18: 2$ and C18:3, and tended $(P<0.07)$ to increase cis -9 , trans -11 CLA proportions in milk fat. Proportion of all transC18:1 isomers, except for trans-12, and the proportion of total trans-C18:1 and total trans-C18 FA were increased when LAHT was fed relative to SAHT. The increase in the proportion of trans-10 C18:1 in milk fat for cows fed LAHT is in agreement with the lower milk fat percentage and yield for this dietary treatment compared with SAHT. Selective sorting against long-stem hay by some animals fed LAHT likely resulted in favorable rumen conditions for the formation of this particular isomer and its successive incorporation into milk fat.

Milk fat content of C16:0 tended $(P<0.06)$ to be lower for cows fed AST relative to cows fed SAHT. Milk fat concentration of $\mathrm{C} 18: 0, \mathrm{C} 18: 2$, and $\mathrm{C} 18: 3$ was higher $(P<0.05, P<0.004$, and $P<0.02$, respectively) in milk fat of cows fed SAHT as compared with cows fed AST. Consistent with milk fat production data, alfalfa preservation method had minimal effects on trans-C18:1 isomer profile and did not affect milk fat content of total trans-C18 FA.

\section{Chewing Behavior}

Chewing activities are presented in Table 6. Cows fed corn silage as the sole forage source spent $196 \mathrm{~min}$ eating and 493 min ruminating per day, regardless of $\mathrm{T}$ content of the diet. However, cows fed CST tended $(P<0.13)$ to spend more time eating per kilogram of DMI, and spent more $(P<0.01)$ time ruminating per kilogram of NDF intake and chewing per kilogram of DMI compared with cows fed CS. These results suggest 
Table 5. Fatty acid composition of milk fat as affected by dietary treatments.

\begin{tabular}{|c|c|c|c|c|c|c|c|c|c|c|}
\hline & \multicolumn{5}{|c|}{ Treatment $^{1}$} & \multirow[b]{2}{*}{$\mathrm{SE}$} & \multicolumn{4}{|c|}{ Statistical contrasts $(P<)^{2}$} \\
\hline & CS & $\mathrm{CST}$ & SAHT & LAHT & AST & & $\mathrm{A}$ & $\mathrm{B}$ & $\mathrm{C}$ & $\mathrm{D}$ \\
\hline Profile & \multicolumn{5}{|c|}{$\longrightarrow \mathrm{g} / 100 \mathrm{~g}$ of fatty acids } & & & & & \\
\hline $\mathrm{C} 4$ to $\mathrm{C} 14$ & 25.0 & 20.6 & 20.8 & 21.2 & 20.9 & 0.8 & 0.001 & NS & NS & NS \\
\hline $\mathrm{C} 16: 0$ & 27.1 & 27.1 & 26.8 & 26.3 & 25.4 & 0.7 & NS & 0.14 & NS & 0.06 \\
\hline C18:0 & 9.6 & 9.9 & 11.4 & 10.3 & 12.1 & 0.6 & NS & 0.02 & 0.05 & NS \\
\hline C18:1 & 22.6 & 27.2 & 26.2 & 26.5 & 27.1 & 0.8 & 0.001 & NS & NS & NS \\
\hline \multicolumn{11}{|l|}{ C18:1 isomers } \\
\hline trans $-6 / 8$ & 0.30 & 0.60 & 0.49 & 0.62 & 0.44 & 0.04 & 0.001 & 0.04 & 0.01 & NS \\
\hline trans -9 & 0.35 & 0.47 & 0.37 & 0.48 & 0.37 & 0.04 & 0.04 & 0.11 & 0.04 & NS \\
\hline trans -10 & 0.75 & 2.15 & 1.00 & 1.71 & 0.78 & 0.22 & 0.001 & 0.001 & 0.01 & NS \\
\hline trans -11 & 0.86 & 0.89 & 0.89 & 1.03 & 1.06 & 0.05 & NS & NS & 0.11 & 0.05 \\
\hline trans-12 & 0.59 & 0.52 & 0.63 & 0.70 & 0.71 & 0.06 & NS & 0.02 & NS & NS \\
\hline Total trans-C18:1 & 2.84 & 4.62 & 3.35 & 4.53 & 3.36 & 0.27 & 0.001 & 0.01 & 0.01 & NS \\
\hline cis-9 & 16.9 & 20.6 & 20.4 & 19.6 & 20.5 & 0.6 & 0.001 & NS & NS & NS \\
\hline cis -11 & 0.22 & 0.12 & 0.23 & 0.30 & 0.24 & 0.05 & NS & 0.03 & NS & NS \\
\hline cis -12 & 0.51 & 0.66 & 0.52 & 0.57 & 0.48 & 0.07 & 0.15 & 0.08 & NS & NS \\
\hline $\mathrm{CLA}^{3}$ c9t11 & 0.49 & 0.60 & 0.50 & 0.57 & 0.62 & 0.04 & 0.02 & $\mathrm{NS}$ & 0.07 & 0.01 \\
\hline CLA t10c12 & 0.01 & 0.04 & 0.02 & 0.03 & 0.03 & 0.005 & 0.002 & 0.04 & NS & NS \\
\hline C18:2 & 5.2 & 4.2 & 4.4 & 5.4 & 5.2 & 0.2 & 0.001 & 0.003 & 0.001 & 0.004 \\
\hline C18:3 & 0.35 & 0.29 & 0.36 & 0.42 & 0.42 & 0.02 & 0.04 & 0.001 & 0.02 & 0.02 \\
\hline Other & 9.5 & 9.9 & 9.6 & 9.2 & 8.2 & 0.7 & NS & NS & NS & 0.09 \\
\hline Total trans ${ }^{4}$ & 3.4 & 5.2 & 3.9 & 5.2 & 4.0 & 0.3 & 0.002 & 0.003 & 0.004 & NS \\
\hline
\end{tabular}

${ }^{1} \mathrm{CS}=50 \%$ corn silage $+50 \%$ concentrate with $0 \%$ tallow; $\mathrm{CST}=50 \%$ corn silage $+50 \%$ concentrate with $2 \%$ tallow; $\mathrm{SAHT}=25 \%$ corn silage $+25 \%$ short alfalfa hay $+50 \%$ concentrate with $2 \%$ tallow; LAHT $=$ $25 \%$ corn silage $+25 \%$ long alfalfa hay $+50 \%$ concentrate with $2 \%$ tallow; AST $=25 \%$ corn silage $+25 \%$ alfalfa silage $+50 \%$ concentrate with $2 \%$ tallow.

${ }^{2} \mathrm{~A}=\mathrm{CS}$ vs. CST; $\mathrm{B}=\mathrm{CST}$ vs. SAHT + LAHT + AST C = SAHT vs. LAHT; D = SAHT vs. AST; NS = not significant.

${ }^{3} \mathrm{CLA}=$ Conjugated linoleic acid.

${ }^{4} \mathrm{C} 18: 1$ isomers plus CLA c9t11 and t10c12.

that cows fed supplemental $\mathrm{T}$ required more time for eating and ruminating as intakes of DM and NDF decreased compared with cows fed the same diet without $\mathrm{T}$. The reason for greater chewing activity for cows fed supplemental $\mathrm{T}$ is not clear. Although all data is not consistent, fat supplementation has been shown to impair fiber digestion in the rumen in some studies (Palmquist and Jenkins, 1980). Decreased rate of ruminal fermentation likely decreases the rate of particle size reduction during chewing by decreasing tissue fragility (Allen, 1996); therefore, more chewing time would be required. However, no effect of $\mathrm{T}$ on rumen fermentation (discussed later) was observed in the present study. The addition of $11.6 \%$ whole raw soybeans had no effect on the chewing activity of lactating cows (Grant and Weidner, 1992).

Table 6. Treatment effects on chewing behavior of cows.

\begin{tabular}{|c|c|c|c|c|c|c|c|c|c|c|}
\hline & \multicolumn{5}{|c|}{ Treatment $^{1}$} & $\mathrm{SE}$ & \multicolumn{4}{|c|}{ Statistical contrasts $(P<)^{2}$} \\
\hline \multicolumn{11}{|l|}{ Eating } \\
\hline Time/DMI, min/kg & 6.9 & 7.6 & 9.3 & 11.2 & 9.2 & 0.4 & 0.13 & 0.001 & 0.001 & NS \\
\hline \multicolumn{11}{|l|}{ Ruminating } \\
\hline Time, min/d & 482.3 & 504.1 & 509.2 & 449.7 & 444.7 & 17.7 & NS & 0.02 & 0.002 & 0.002 \\
\hline Time, $\min / \mathrm{d}$ & 676.8 & 700.0 & 759.2 & 745.0 & 690.7 & 20.8 & NS & 0.08 & NS & 0.01 \\
\hline Time/DMI, min/kg & 24.5 & 27.2 & 28.2 & 28.3 & 26.1 & 1.1 & 0.01 & NS & NS & 0.03 \\
\hline
\end{tabular}

${ }^{1} \mathrm{CS}=50 \%$ corn silage $+50 \%$ concentrate with $0 \%$ tallow; CST $=50 \%$ corn silage $+50 \%$ concentrate with $2 \%$ tallow; SAHT $=25 \%$ corn silage $+25 \%$ short alfalfa hay $+50 \%$ concentrate with $2 \%$ tallow; LAHT $=25 \%$ corn silage $+25 \%$ long alfalfa hay $+50 \%$ concentrate with $2 \%$ tallow; $\mathrm{AST}=25 \%$ corn silage $+25 \%$ alfalfa silage $+50 \%$ concentrate with $2 \%$ tallow.

${ }^{2} \mathrm{~A}=\mathrm{CS}$ vs. CST; B = CST vs. SAHT + LAHT + AST; C = SAHT vs. LAHT; D = SAHT vs. AST; NS = not significant. 
Replacing $50 \%$ of corn silage with alfalfa in diets with $2 \% \mathrm{~T}$ increased $(P<0.001)$ the total time spent eating per day and eating time per kilogram of DMI, and it decreased total time spent ruminating and rumination time/kg NDF $(P<0.02$ and $P<0.03$, respectively). Increased eating time suggests that cows needed more chews to achieve the critical particle size required for swallowing when alfalfa was included in the diets. Despite lower rumination activity, total time spent chewing tended $(P<0.08)$ to be higher for cows fed alfalfa and corn silage compared with all corn silage when diets contained $\mathrm{T}$. This trend for an increase in chewing activity when alfalfa replaced half of the corn silage in tallow-containing diets was associated with higher milk fat percentage and yield.

Cows fed LAHT spent more time eating per day and more time eating per kilogram of DMI than cows fed SAHT $(P<0.001)$. Contrary to our expectations, total time spent ruminating, as well as time spent ruminating per kilogram of NDF intake was lower for cows fed LAHT than for cows fed SAHT $(P<0.001$ and $P<$ 0.07 , respectively). The reason for this behavior is not obvious. Greater chewing prior to swallowing for cows fed LAHT probably reduced particle size to a greater extent than for cows fed SAHT, reducing the need for rumination. On the other hand, cows fed LAHT sorted against long particles rich in fiber, likely resulting in less need for rumination. Total time spent chewing by cows was similar for both treatments. Therefore, decreasing particle size of hay in this study did not alter the physical effectiveness of forage NDF. According to Mertens (1997), chewing activity is the animal response associated with physical effectiveness of fiber because it promotes salivary buffer secretion during eating and rumination. These results suggest that factors other than chewing activity might be responsible for reduced milk fat content when tallow is fed with long-stem hay compared with chopped hay.

Time spent eating was similar for cows fed SAHT and AST. Cows fed SAHT spent more time ruminating than cows fed AST $(P<0.002)$. This difference was not only due to less NDF intake of cows fed AST, because time spent ruminating per kilogram of NDF intake was also decreased $(P<0.04)$ by cows fed AST. Total chewing time and time spent chewing per kilogram of DMI was significantly $(P<0.01$ and $P<0.03$, respectively) higher for cows fed SAHT vs. cows fed AST. Nelson and Satter (1990) reported greater time spent ruminating and chewing per kilogram of NDF for cows consuming diets consisting of $55 \%$ alfalfa hay than cows consuming the same amount of alfalfa silage. These authors concluded that alfalfa silage particles were reduced in size or were adequately wetted for swallowing in less time. Increased rumination and chewing time of cows fed chopped alfalfa hay vs. feeding alfalfa silage of similar particle length and distribution was not associated with increased milk fat yield in the present study.

\section{Rumen Fermentation}

Rumen $\mathrm{pH}, \mathrm{NH}_{3}-\mathrm{N}$, and total VFA concentrations, as well as molar proportion of VFA as affected by dietary treatments, are shown in Table 7 . No treatment $\times$ time interactions were detected for any of the variables measured. Ruminal pH was not affected by supplemental $\mathrm{T}$ when corn silage was the only forage source. Similar results were observed in our previous studies (Onetti et al., 2001, 2003). Cows fed diets with supplemental $\mathrm{T}$ in which alfalfa replaced $50 \%$ of the corn silage had higher ruminal $\mathrm{pH}(P<0.02)$. Lower ruminal $\mathrm{pH}$ of cows fed diets with corn silage as the only forage source might be partially explained by the high availability of rapidly fermentable starch due to corn silage processing, lower buffering capacity of corn silage relative to alfalfa, and decreased chewing activity. Ruminal $\mathrm{pH}$ was higher $(P<0.03)$ for cows fed LAHT than SAHT. However, this increase in $\mathrm{pH}$ was not related to chewing behavior, as time spent chewing was similar for LAHT and SAHT. There was no effect of alfalfa preservation method on ruminal $\mathrm{pH}$, even though chewing activity was greater for cows fed SAHT than for cows fed AST.

Ruminal $\mathrm{NH}_{3}-\mathrm{N}$ concentration tended $(P<0.07)$ to decrease when $\mathrm{T}$ was added to corn silage diets, similar to our previous report (Onetti et al., 2001). Reduction in ruminal $\mathrm{NH}_{3}-\mathrm{N}$ concentration when fats are fed has been associated with decreased numbers of protozoa and decreased microbial nitrogen recycling (Ikwuegbu and Sutton, 1982; Onetti et al., 2001). No effect of replacing corn silage with alfalfa was observed on $\mathrm{NH}_{3}$ $\mathrm{N}$ concentration. Increasing the proportion of alfalfa silage in the diets increased ruminal $\mathrm{NH}_{3}-\mathrm{N}$ concentration at $4 \mathrm{~h}$ postfeeding when $2 \% \mathrm{~T}$ was fed in a previous study (Onetti et al., 2002). Cows fed LAHT had lower $(P<0.01)$ ruminal $\mathrm{NH}_{3}-\mathrm{N}$ concentration than cows fed SAHT. No effect of forage particle length on ruminal $\mathrm{NH}_{3}-\mathrm{N}$ was reported in the study by Yang et al. (2001). Ruminal $\mathrm{NH}_{3}-\mathrm{N}$ concentration was similar for cows fed alfalfa preserved either as silage or hay.

A trend $(P<0.08)$ for a decrease in total VFA concentration was observed when $\mathrm{T}$ was included in diets with corn silage as the sole forage source, probably as a result of lower DMI. No effect of T was observed on molar proportions of individual VFA or A:P when corn silage was the only forage source. Total VFA concentration did not differ when alfalfa replaced corn silage in diets containing tallow. Replacing corn silage with alfalfa in diets with $2 \%$ T increased $(P<0.001)$ the molar proportion of acetate, decreased $(P<0.002)$ the molar propor- 
Table 7. Effects of dietary treatments on rumen $\mathrm{pH}$, ammonia and VFA concentrations and molar proportion of VFA.

\begin{tabular}{|c|c|c|c|c|c|c|c|c|c|c|}
\hline & \multicolumn{5}{|c|}{ Treatment $^{1}$} & \multirow[b]{2}{*}{$\mathrm{SE}$} & \multicolumn{4}{|c|}{ Statistical contrasts $(P<)^{2}$} \\
\hline & CS & CST & SAHT & LAHT & AST & & A & B & $\mathrm{C}$ & $\mathrm{D}$ \\
\hline $\mathrm{pH}$ & 6.23 & 6.26 & 6.32 & 6.40 & 6.31 & 0.05 & NS & 0.02 & 0.03 & NS \\
\hline $\mathrm{NH}_{3}-\mathrm{N}, \mathrm{mg} / \mathrm{dl}$ & 11.5 & 9.8 & 10.3 & 7.7 & 9.1 & 0.8 & 0.07 & NS & 0.01 & NS \\
\hline $\mathrm{VFA},{ }^{3} \mathrm{mM}$ & 120.6 & 114.5 & 120.8 & 111.5 & 114.2 & 3.1 & 0.08 & NS & 0.01 & 0.04 \\
\hline Acetate & 62.5 & 61.4 & 65.1 & 65.4 & 65.9 & 0.7 & NS & 0.001 & NS & NS \\
\hline Propionate & 21.9 & 23.4 & 20.1 & 20.1 & 18.9 & 0.8 & NS & 0.002 & NS & NS \\
\hline Butyrate & 11.9 & 11.4 & 11.0 & 10.9 & 11.5 & 0.4 & NS & NS & NS & NS \\
\hline Isobutyrate & 0.7 & 0.6 & 0.8 & 0.7 & 0.8 & 0.04 & NS & 0.01 & NS & NS \\
\hline Isovalerate & 1.4 & 1.5 & 1.3 & 1.3 & 1.5 & 0.08 & NS & NS & NS & NS \\
\hline Valerate & 1.7 & 1.6 & 1.7 & 1.6 & 1.5 & 0.06 & NS & NS & 0.04 & 0.01 \\
\hline $\mathrm{A}: \mathrm{P}^{4}$ & 2.9 & 2.7 & 3.3 & 3.4 & 3.6 & 0.1 & NS & 0.001 & NS & NS \\
\hline
\end{tabular}

${ }^{1} \mathrm{CS}=50 \%$ corn silage $+50 \%$ concentrate with $0 \%$ tallow; CST $=50 \%$ corn silage $+50 \%$ concentrate with $2 \%$ tallow; $\mathrm{SAHT}=25 \%$ corn silage $+25 \%$ short alfalfa hay $+50 \%$ concentrate with $2 \%$ tallow; LAHT $=$ $25 \%$ corn silage $+25 \%$ long alfalfa hay $+50 \%$ concentrate with $2 \%$ tallow; AST $=25 \%$ corn silage $+25 \%$ alfalfa silage $+50 \%$ concentrate with $2 \%$ tallow.

${ }^{2} \mathrm{~A}=\mathrm{CS}$ vs. CST; $\mathrm{B}=\mathrm{CST}$ SAHT + LAHT + AST; C = SAHT vs. LAHT; D = SAHT vs. AST; NS = not significant.

${ }^{3}$ Total VFA.

${ }^{4}$ Acetate-to-propionate ratio.

tion of propionate and, consequently, increased $(P<$ $0.001) \mathrm{A}: \mathrm{P}$ in the rumen. Similar results were observed in our previous study (Onetti et al., 2002). Consistent with increased ruminal $\mathrm{pH}$, cows fed LAHT had lower $(P<0.01)$ total VFA concentration in the rumen than cows fed SAHT. No effect of alfalfa hay particle size was observed on molar proportions of individual VFA, except for an increase $(P<0.04)$ in the proportion of valerate when SAHT was fed vs. LAHT. Total VFA concentration was lower $(P<0.04)$ for cows fed AST compared with SAHT. The effect of the alfalfa preservation method on molar proportions of individual VFA was minor; an increase $(P<0.01)$ in the proportion of valerate was observed for cows fed SAHT vs. AST. Changes in molar proportions valerate due to dietary treatments were small and difficult to interpret. Based on these results and those of our previous study (Onetti et al., 2002), the milk fat depression observed when $2 \%$ $\mathrm{T}$ was fed with diets with corn silage as the only forage source or with diets with long-stem alfalfa hay appears to be independent of rumen $\mathrm{pH}$ or shifts in rumen fermentation.

\section{Intake, Omasal Flow, and Biohydrogenation of Fatty Acids}

Dietary effects on intake and omasal flow of C18 FA, and the extent of biohydrogenation of unsaturated FA in the rumen are presented in Table 8. Intakes of C18:0, trans-C18:1, and cis-C18:1 were increased $(P<0.02)$, that of C18:2 was not affected, and intake of C18:3 tended to decrease $(P<0.08)$ when $\mathrm{T}$ was added to diets with corn silage as the only forage source. These changes reflected changes in FA composition of the diets and in DMI of cows. Despite the reduction in DMI due to $\mathrm{T}$ supplementation, intake of total $\mathrm{C} 18 \mathrm{FA}$ tended $(P<0.08)$ to be higher for cows fed CST than for cows fed CS. Replacing corn silage with alfalfa in T containing diets tended $(P<0.13)$ to decrease intake of C18:2 and significantly $(P<0.02)$ increased intake of C18:3. Total intake of C18 FA was similar for tallowcontaining diets, regardless of forage treatment. Intakes of C18:2 and C18:3 tended to be higher for cows fed LAHT compared with cows fed SAHT. Higher intakes of these polyunsaturated FA might be explained by the slightly higher concentration in the diet or proportionally higher concentrate and corn silage intakes relative to hay due to sorting against the long-stem hay. There was a trend $(P<0.09)$ for a decrease in trans-C18:1 intake of cows fed LAHT vs. SAHT, and of cows fed AST vs. SAHT, probably due to the lower concentration of this particular FA in the diets.

Supplemental tallow significantly increased $(P<$ $0.03)$ omasal flow of trans-C18:1 and tended $(P<0.12)$ to increase flow of total C18 FA when corn silage was the only forage source. Increased flow of trans-C18:1 might be related to increased intake, incomplete $\mathrm{BH}$ or isomerization of cis-C18:1 in the rumen. Mosley et al. (2002) showed that BH of oleic acid by mixed rumen bacteria involves the formation of several positional trans-C18:1 isomers. It is not known whether the transC18:1 isomers derived from oleic acid are intermediates or end products of $\mathrm{BH}$ in the rumen (Mosley et al., 2002). Replacing $50 \%$ of the corn silage with alfalfa 
Table 8. Effects of dietary treatments on fatty acid intake and omasal flow and extent of ruminal biohydrogenation.

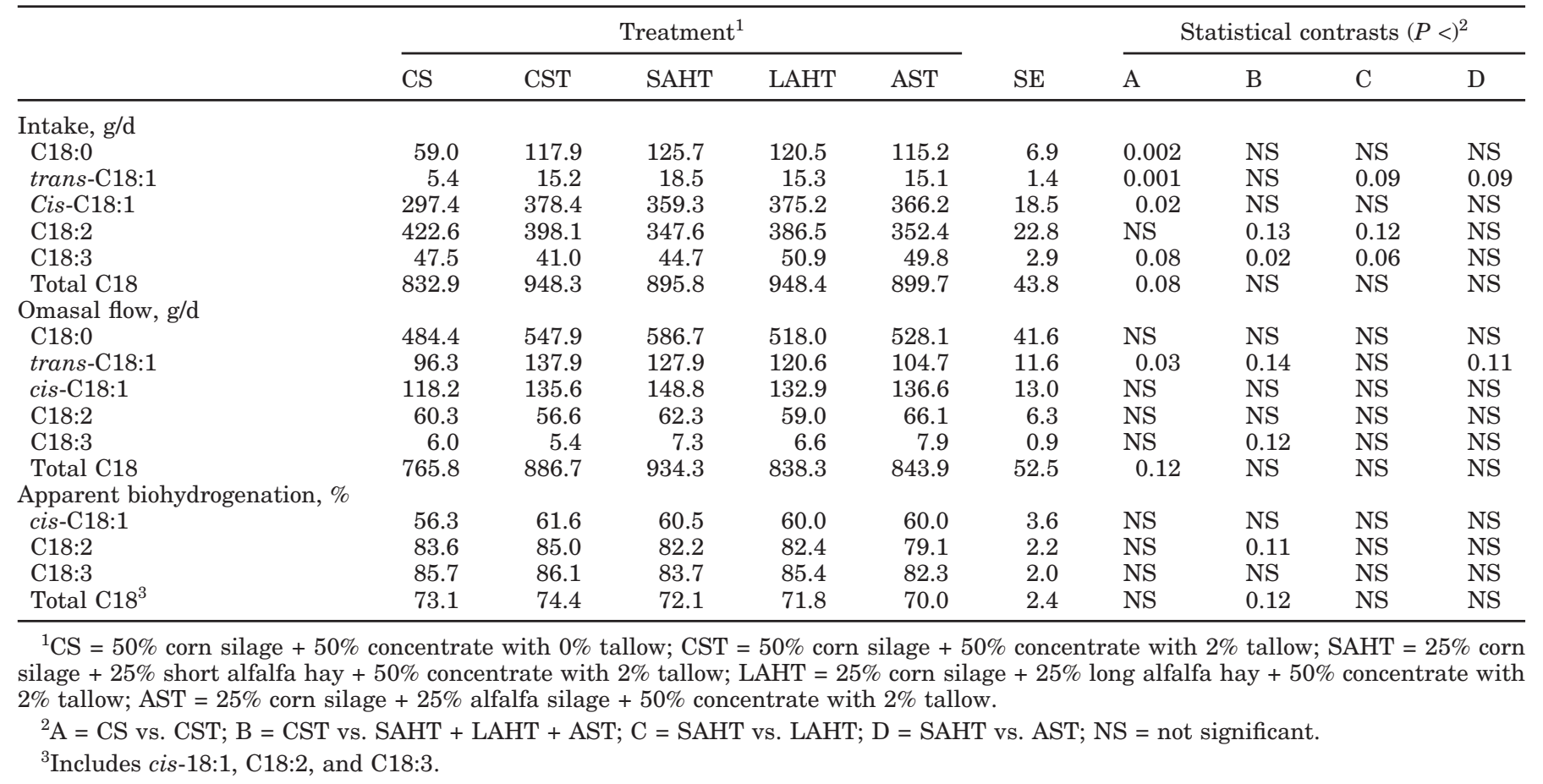

when supplemental tallow was fed tended $(P<0.14)$ to decrease flow of trans-C18:1, suggesting a more complete $\mathrm{BH}$. The trend $(P<0.12)$ for increased flow of C18:3 when alfalfa replaced corn silage was likely due to higher C18:3 intake. Alfalfa hay particle length resulted in no significant differences in individual or total FA flows. We hypothesized that feeding long hay would decrease trans-C18:1 FA flow to the lower gut relative to feeding chopped hay as a result of increased ruminal $\mathrm{pH}$. However, the response to LAHT treatment was highly influenced by selective sorting against long-stem hay by some cows. Feeding AST tended $(P<0.11)$ to decrease flow of trans-C18:1 relative to feeding SAHT. The reason for this trend is not obvious as intake of trans-C18:1 was only $3.4 \mathrm{~g} / \mathrm{d}$ higher for SAHT when compared with AST.

Similar to previous reports (Wu et al., 1991; Kalscheur et al. 1997), the extent of apparent ruminal $\mathrm{BH}$ increased as the degree of unsaturation increased. Biohydrogenation of individual or total unsaturated C18 FA was similar between CS and CST. By using this estimate of $\mathrm{BH}$, incomplete $\mathrm{BH}$ of $\mathrm{C} 18: 2$ and $\mathrm{C} 18: 3$ would be reflected in lower apparent $\mathrm{BH}$ for cis-C18:1 and C18:2, respectively. In the present study, increased trans-10 C18:1 and trans-10, cis-12 C18:2 contents in milk fat, when tallow was supplemented with diets with corn silage as the only forage source, appears not to be caused by incomplete $\mathrm{BH}$ of polyunsaturated FA in the rumen. No difference in apparent $\mathrm{BH}$ was observed for cows fed CS and CST. This is in agreement with the lack of effect of supplemental tallow on ruminal $\mathrm{pH}$ and fermentation. Consequently, the increased content of trans-C18:1 isomers in milk fat observed might be explained by accumulation of trans-C18:1 in the rumen from the BH of oleic acid (Mosley et al., 2002). Tallow contributed significant amounts of cis-C18:1 to the diets. When diets high in corn silage are fed, characteristics of the rumen environment probably cause shifts in the bacterial population favoring those species capable of converting cis-C18:1 to trans-C18:1 isomers. Increased proportion of trans-10, cis-12 CLA in milk fat was associated with increased flow of this particular FA out of the rumen (omasal flow of trans-10, cis-12 CLA was 0.7 and $1.5 \mathrm{~g} / \mathrm{d}$ for CS and CST, respectively, $P<0.06$, data not shown). It appears that trans-10, cis12 CLA is formed from hydrogenation of linoleic acid when milk fat depressing diets are fed (Bauman and Griinari, 2001).

When half of the corn silage was replaced with alfalfa in diets containing tallow, apparent ruminal $\mathrm{BH}$ of C18:2 and of total C18 tended $(P<0.12)$ to decrease. These results are in disagreement with the trend for an increased flow of trans-C18:1 at the omasal canal observed for CST. Conversion of trans-C18:1 to C18:0 is the rate-limiting step in $\mathrm{BH}$ of polyunsaturated FA, leading to accumulation of trans-C18:1 in the rumen (Harfoot and Hazlewood, 1988). Kalscheur et al. (1997) demonstrated the direct effect of ruminal $\mathrm{pH}$ on produc- 
tion of trans FA in the rumen. These researchers showed that feeding a high concentrate low forage diet without buffer increased the flow of trans-C18:1 FA compared with the same diet with buffer. Replacing corn silage with alfalfa decreased $(P<0.02)$ flow of trans-10, cis-12 CLA (data not shown). Decreasing dietary forage-to-concentrate ratio resulted in decreased ruminal $\mathrm{pH}$ and an increase in duodenal flow of trans10, cis-12 CLA in sheep (Kucuk et al., 2001). In the present study, ruminal $\mathrm{pH}$ was lower for diets with corn silage as the only forage source. Alfalfa hay particle length or alfalfa preservation method did not affect $\mathrm{BH}$ of unsaturated FA in the rumen.

\section{CONCLUSIONS}

Milk fat percentage and yield of cows were decreased when tallow was fed at $2 \%$ of diet DM with diets of corn silage as the only forage source. Milk fat depression was associated with increased trans-C18:1 FA flowing out of the rumen and their subsequent incorporation into milk fat. Trans-C18:1 FA in the rumen appear to be formed during the biohydrogenation of oleic acid. Replacing 50\% of corn silage with alfalfa in diets containing $2 \%$ tallow resulted in increased chewing activity, higher ruminal $\mathrm{pH}$, lower formation of trans-C18:1 FA in the rumen, and increased milk fat percentage and yield. The results suggest that alfalfa, regardless of the preservation method, is more effective in sustaining milk fat production than processed corn silage when $2 \%$ supplemental tallow is fed. However, feeding longstem hay might be less effective than chopped hay in maintaining milk fat production if selective sorting against long particles occurs in the manger.

\section{AKNOWLEDGMENTS}

The authors thank the Fats and Proteins Research Foundation for partial funding of this study and Packerland Packing Co., Inc. (Green Bay, WI) for donating the tallow. Appreciation is expressed to the UW Dairy Cattle Research Center crew for animal care and feeding.

\section{REFERENCES}

Allen, D. M., and R. J. Grant. 2000. Interactions between forage and wet corn gluten feed as sources of fiber in diets for lactating dairy cows. J. Dairy Sci. 83:322-331.

Allen, M. S. 1996. Physical constraints on voluntary intake of forages by ruminants. J. Anim. Sci. 74:3063-3075.

Allen, M. S. 1997. Relationship between fermentation acid production in the rumen and the requirement for physically effective fiber. J. Dairy Sci. 80:1447-1462.

Ahvenjärvi, S., A. Vanhatalo, P. Huhtanen, and T. Varvikko. 2000. Determination of reticulo-rumen and whole-stomach digestion in lactating cows by omasal canal and duodenal sampling. Br. J. Nutr. 83:67-77.
American National Standards Institute. 1988. Method of determining and expressing particle size of chopped forage materials for screening. ASAE S424.

Association of Official Analytical Chemists. 1990. Official Methods of Analysis. Vol. I. 15th ed. AOAC, Arlington, VA.

Bal, M. A., R. D. Shaver, A. G. Jirovec, K. J. Shinners, and J. G. Coors. 2000. Crop processing and chop length of corn silage: Effects on intake, digestion, and milk production by dairy cows. J. Dairy Sci. 83:1264-1273.

Bauman, D. E., and J. M. Griinari. 2001. Regulation and nutritional manipulation of milk fat: Low-fat milk syndrome. Livest. Prod. Sci. 70:15-29.

Baumgard, L. H., B. A. Corl, D. A. Dwyer, A. Saebo, and D. E. Bauman. 2000. Identification of the conjugated linoleic acid isomer that inhibits milk fat synthesis. Am. J. Physiol. 278:R179-R184.

Beauchemin, K. A., and J. G. Buchanan-Smith. 1989. Effects of dietary neutral detergent fiber concentration and supplementary long hay on chewing activities and milk production of dairy cows. J. Dairy Sci. 72:2288-2300.

Chaney, A. L., and E. P. Marbach. 1962. Modified reagents for determination of urea and ammonia. Clin. Chem. 8:130-132.

Chouinard, P. Y., L. Corneau, D. M. Barbano, L. E. Metzger, and D. E. Bauman. 1999. Conjugated linoleic acids alter milk fatty acid composition and inhibit milk fat secretion in dairy cows. J. Nutr. 129:1579-1584

Combs, D. K., and L. D. Satter. 1992. Determination of markers in digesta and feces by direct current plasma emission-spectroscopy. J. Dairy Sci. 75:2176-2183.

France, J., and R. C. Siddons. 1986. Determination of digesta flow by continuous marker infusion. J. Theor. Biol. 121:105-119.

Grant, R. J., and S. J. Weidner. 1992. Effect of fat from whole soybeans on performance of dairy cows fed rations differing in fiber level and particle size. J. Dairy Sci. 75:2742-2751.

Griinari, J. M., D. A. Dwyer, M. A. McGuire, D. E. Bauman, D. L. Palmquist, and K.V. V. Nurmela. 1998. Trans-octadecenoic acids and milk fat depression in lactating dairy cows. J. Dairy Sci. 81:1251-1261.

Harfoot, C. G., and G. P. Hazlewood. 1988. Lipid metabolism in the rumen. Page 285 in The Rumen Microbial Ecosystem. P. N. Hobson, ed. Elsevier Appl. Sci., London, England.

Huhtanen, P. S., S. Kaustell, and S. Jaakkola. 1994. The use of internal markers to predict total digestibility and duodenal flow of nutrients in cattle given six different diets. Anim. Feed Sci. Technol. 48:211-227.

Huhtanen, P. S., P. G. Brotz, and L. D. Satter. 1997. Omasal sampling technique for assessing fermentative digestion in the forestomach of dairy cows. J. Anim. Sci. 75:1380-1392.

Ikwuegbu, O. A., and J. D. Sutton. 1982. The effect of varying the amount of linseed oil supplementation on rumen metabolism in sheep. Br. J. Nutr. 48:365-375.

Kalscheur, K. F., B. B. Teter, L. S. Piperova, and R. D. Erdman. 1997. Effect of dietary forage concentration and buffer addition on duodenal flow of trans-C18:1 fatty acids and milk fat production in dairy cows. J. Dairy Sci. 80:2104-2114.

Kucuk, O., B. W. Hess, P. A. Ludden, and D. C. Rule. 2001. Effect of forage:concentrate ratio on ruminal digestion and duodenal flow of fatty acids in ewes. J. Anim. Sci. 79:2233-2240.

Leonardi, C., and L. E. Armentano. 2003. Effect of quantity, quality, and length of alfalfa hay on selective consumption by dairy cows. J. Dairy Sci. 86:557-564.

Mertens, D. R. 1997. Creating a system for meeting the fiber requirements of dairy cows. J. Dairy Sci. 80:1463-1481.

Mertens, D. R. 1999. Variation in aNDF results with modifications of the filter bag method. National Forage Testing Association, Technical Session Papers and Committee Reports to the Board and Membership, June 1999, Topeka, KS.

Mosley, E. E., G. L. Powell, M. B. Riley, and T. C. Jenkins. 2002. Microbial biohydrogenation of oleic acid to trans isomers in vitro. J. Lipid Res. 43:290-296.

National Research Council. 2001. Nutrient Requirements of Dairy Cattle. 7th rev. ed. Natl. Acad. Press, Washington, DC. 
Nelson, W. F., and L. D. Satter. 1990. Effect of stage of maturity and method of preservation of alfalfa on production by lactating dairy cows. J. Dairy Sci. 73:1800-1811.

Onetti, S. G., R. D. Shaver, M. A. McGuire, and R. R. Grummer. 2001. Effect of type and level of dietary fat on rumen fermentation and performance of dairy cows fed corn silage-based diets. J. Dairy Sci. 84:2751-2759.

Onetti, S. G., R. D. Shaver, M. A. McGuire, D. L. Palmquist, and R. R. Grummer. 2002. Effect of supplemental tallow on performance of dairy cows fed diets with different corn silage:alfalfa silage ratios. J. Dairy Sci. 85:632-641.

Onetti, S. G., R. D. Shaver, S. J. Bertics, and R. R. Grummer. 2003. Influence of corn silage particle length on the performance of lactating dairy cows fed supplemental tallow. J. Dairy Sci. 86: 2949-2957.

Palmquist, D. L., and T. C. Jenkins. 1980. Fat in lactation rations: Review. J. Dairy Sci. 63:1-14.

Ruppert, L. D., J. K. Drackley, D. R. Bremmer, and J. H. Clark. 2003. Effects of tallow in diets based on corn silage or alfalfa silage on digestion and nutrient use by lactating dairy cows. J. Dairy Sci. 86:593-609.

SAS User's Guide: Statistics, Version 8 Edition. 2001. SAS Inst., Inc., Cary, NC.

Siddons, R. C., J. Paradine, D. E. Beever, and P. R. Cornell. 1985. Ytterbium acetate as a particulate phase digesta-flow marker. Br. J. Nutr. 54:509-519.
Smith, W. A., B. Harris, Jr., H. H. Van Horn, and C. J. Wilcox. 1993. Effect of forage type on production of dairy cows supplemented with whole cottonseed, tallow, and yeast. J. Dairy Sci. 76:205-215.

Stine, C. M., H. A. Harland, S. T. Coulter, and R. Jenness. 1954. A modified peroxide test for detection of lipid oxidation in dairy products. J. Dairy Sci. 37:202-208.

Sukhija, P. S., and D. L. Palmquist. 1988. Rapid method for determination of total fatty acid content and composition of feedstuffs and feces. J. Agric. Food Chem. 36:1202-1206.

Uden, P., P. E. Colucci, and P. J. VanSoest. 1980. Investigation of chromium, cerium and cobalt as markers in digesta. Rate of passage studies. J. Sci. Food Agric. 31:625-632.

Vagnoni, D. B., and G. A. Broderick. 1997. Effects of supplementation of energy or ruminally undegraded protein to lactating cows fed alfalfa hay or silage. J. Dairy Sci. 80:1703-1712.

Wu, Z., O. A. Ohajuruka, and D. L. Palmquist. 1991. Ruminal synthesis, biohydrogenation, and digestibility of fatty acids by dairy cows. J. Dairy Sci. 74:3025-3034.

Wu, Z., and J. T. Huber. 1994. Relationship between dietary fat supplementation and milk protein concentration in lactation cows: A review. Livest. Prod. Sci. 39:141-155.

Yang, W. Z., K. A. Beauchemin, and L. M. Rode. 2001. Effects of grain processing, forage to concentrate ratio, and forage particle size on rumen $\mathrm{pH}$ and digestion by dairy cows. J. Dairy Sci. 84:2203-2216. 